ISSN 0258-7122

Bangladesh J. Agril. Res. 35(3) : 359-366, September 2010

\title{
EFFECT OF PLRV INFECTED SEED TUBER ON DISEASE INCIDENCE, PLANT GROWTH AND YIELD PARAMETERS OF POTATO
}

\author{
M.S. RAHMAN ${ }^{1}$ AND A.M. AKANDA ${ }^{2}$
}

\begin{abstract}
An investigation was conducted to find out the effect of PLRV infected seed tubers on disease incidence, plant growth, and tuber yield of potato. The levels of PLRV infected seed tubers were $0,10,20$, 33, and 100\%. Presence of PLRV infected tubers at $20 \%$ and higher rate caused significant increase in disease incidence and reduction in plant height, stem number, tuber number, and tuber yield as compared to that in control. Incidence of PLRV in the experimental fields, reduction in plant height, stem number, tuber number, and tuber weight per hill was positively and linearly correlated with levels of their inoculum. Spraying of Nimbicidine against insect vector did not show significant influence on plant growth and tuber yield.
\end{abstract}

Keywords: Inoculum levels, disease incidence, PLRV, insecticide, growth and yield performance, potato.

\section{Introduction}

Yield loss of potato due to PLRV infection may vary from 20 to $90 \%$ as reported in different countries (Harper et al.,1975; Khan et al., 1991; Halim, 1999). The extent of yield loss depends on the percentage of PLRV infected plants in the field as well as on the time of infection. With 100\% PLRV infected plants in the field caused 78\% yield loss in Bangladesh (Hossain et al., 1989). The level of PLRV inoculum present in the field ensures the percentage of spread of PLRV in the plants growing in the field since the virus is persistently transmitted by aphid vector. Verhocks (1965) recorded 58.43\% reduction of plant height over control due to $100 \%$ inoculun level of PLRV in the variety Cardinal. It seems that yield loss as well as extent of degeneration due to PLRV infection in plants is correlated with the time of infection i.e., early infection causes severe damage (Robertson, 1978; Khurana and Singh, 1986). Moreover, Khurana and Singh (1986) reported that early infection of PLRV resulting epiphytotic development of the disease was correlated with the level of PLRV inoculum initially present in the field. Thus, every year, a remarkable percentage of yield of potato is reduced due to PLRV infection. So, the present study was undertaken to assess the effect of different levels of PLRV infected seed tubers on the spread of the virus in a potato field under spraying and non-spraying conditions of insecticide including its effect on growth and yield of potato variety Diamant.

${ }^{1}$ Ph.D Student, Bangabandhu Sheikh Mujibur Rahman Agricultural University (BSMRAU), Gazipur, ${ }^{2}$ Professor, Department of Plant Pathology, Bangabandhu Sheikh Mujibur Rahman Agricultural University (BSMRAU), Gazipur, Bangladesh. 


\section{Materials and Method}

The experiment was conducted during 2005-06 crop season using potato variety Diamant. Healthy and PLRV infected potato seed tubers were collected from Foundation Seed Potato Production Farm, Bangladesh Agricultural Development Corporation (BADC), Domar and multiplied at Research Farm of Bangabandhu Sheikh Mujibur Ralmian Agricultural University (BSMRAU), Gazipur under insect proof nets, so that aphid vector could not spread the virus among the plants. The identification of PLRV infected plants was confirmed by DASELISA test using specific antiserum (PathoScreen Kit, supplied by Agdia Incorporated, USA) following the fundamental protocol outlined by Clark and Adams (1977) and modified by Akanda et al. (1991). The inoculum level was maintained at $0,10,20,30$, and $100 \%$ by mixing $0,10,20,30$, and 100 PLRV infected tubers with $100,90,80,70$, and 0 healthy seed tubers. Fertilizers were applied at 350-250-270-120-120-106 kg/ha of urea, TSP, MP, gvpsiun, magnesium sulphate, zinc sulphate, and borax, respectively, as recommended for the country (Anon., 2004). One half of urea and full dose of all other fertilizers were applied at the time of planting. Other half of urea was applied as side dressing after 35 days of planting when first earthling up was done. During land preparation, cowdung was applied at $10 \mathrm{t} / \mathrm{ha}$. The experiment was laid out following randomized complete block design with four replications. The unit plot size was $3.0 \mathrm{~m} \times 1.8 \mathrm{~m}$ where 30 tubers were accommodated at $60 \mathrm{~cm} \times 30 \mathrm{~cm}$ spacing. Infected tubers were distributed uniformly at planting in the plots. Wheat was sown around each plot as barrier of aphids. Intercultural operations, such as irrigation, weeding, mulching, and earthling up were done as and when necessary. The fungicide Dithane M- 45 was applied at $0.25 \%$ to protect the crop from fungal diseases. There were two sets of plots, one for insecticide sprayed and another for non-sprayed condition. The seed tubers were planted on 29 November 2005. In the spraying experiment, Nimbicidine at the rate of 2 litres/ha was sprayed from the $7^{\text {th }}$ day after emergence and continued upto haulm pulling at 7 days interval. Haulm pulling was done ten days before harvesting with a view to avoiding the spread of viruses and for hardening of tuber skin. Ninety days after planting, the crop was harvested on 11 March 2006. Tubers were grouped into four different grades using a standard potato tuber grader of BADC. The grades of the tubers were $<28 \mathrm{~mm}, 28-40 \mathrm{~mm}, 41-55 \mathrm{~mm}$, and $>55 \mathrm{~mm}$, which were designated as A, B and over size, respectively. Occurrence of each grade was expressed in percentage based on total tubers by number, and by weight. Data on virus incidence, plant height $(\mathrm{cm})$, stem number, tuber number and tuber weight per hill, grading by number and weight of tuber were recorded,

\section{Results and Discussion}

Incidence: Incidence of PLRV infected plants was 3.33\% where 100\% healthy tubers were planted, whereas $100 \%$ plants were infected with the virus where 
$100 \%$ infected seed tubers were planted irrespective of non-sprayed and insecticide sprayed conditions. At 10, 20, and 30\% PLRV infected seed tubers, the incidence of PLRV was 6.48, 11.46, and $16.67 \%$ under non-sprayed condition and 3.77, 7.29, and 15.48\% under insecticide sprayed condition, respectively, the differences in PLRV incidence at different levels of infected seed tubers were significant. However, the disease incidence was slightly higher under non-sprayed condition as compared to sprayed condition (Table 1).

Table 1. Effect of PLRV infected seed tubers on incldence of the virus, plant growth and yield parameters of potato.

\begin{tabular}{l|l|c|c|c|c}
\hline $\begin{array}{l}\text { Level of inoculum (\% infected } \\
\text { tuber) }\end{array}$ & $\begin{array}{c}\text { Incidence } \\
\text { of PLRV } \\
(\%)\end{array}$ & $\begin{array}{c}\text { Plant } \\
\text { height } \\
(\mathrm{cm})\end{array}$ & $\begin{array}{c}\text { Stems/ } \\
\text { hill }\end{array}$ & $\begin{array}{c}\text { Tubers/ } \\
\text { hill }\end{array}$ & $\begin{array}{c}\text { Tuber wt } \\
(\mathrm{g}) / \mathrm{hill}\end{array}$ \\
\hline Non-sprayed condition & & & & & \\
0 & $3.33 \mathrm{e}$ & $59.84 \mathrm{a}$ & $8.76 \mathrm{a}$ & $9.23 \mathrm{a}$ & $448.20 \mathrm{~b}$ \\
10 & $6.48 \mathrm{~d}$ & $56.20 \mathrm{~b}$ & $7.41 \mathrm{~b}$ & $8.91 \mathrm{a}$ & $428.00 \mathrm{c}$ \\
20 & $11.46 \mathrm{c}$ & $51.20 \mathrm{~cd}$ & $5.98 \mathrm{c}$ & $7.98 \mathrm{~b}$ & $359.10 \mathrm{e}$ \\
30 & $16.67 \mathrm{~b}$ & $49.04 \mathrm{~d}$ & $5.50 \mathrm{c}$ & $7.28 \mathrm{c}$ & $321.80 \mathrm{~g}$ \\
100 & $100.00 \mathrm{a}$ & $41.98 \mathrm{f}$ & $4.00 \mathrm{~d}$ & $5.02 \mathrm{~d}$ & $175.70 \mathrm{i}$ \\
Insecticide sprayed condition & & & & & \\
0 & $3.33 \mathrm{e}$ & $61.42 \mathrm{a}$ & $9.06 \mathrm{a}$ & $9.24 \mathrm{a}$ & $456.70 \mathrm{a}$ \\
10 & $3.77 \mathrm{~d}$ & $55.67 \mathrm{~h}$ & $7.67 \mathrm{~b}$ & $9.07 \mathrm{a}$ & $446.00 \mathrm{~b}$ \\
20 & $7.29 \mathrm{c}$ & $52.17 \mathrm{c}$ & $6.18 \mathrm{c}$ & $8.11 \mathrm{~h}$ & $372.50 \mathrm{~d}$ \\
30 & $15.48 \mathrm{~b}$ & $49.78 \mathrm{~cd}$ & $5.77 \mathrm{c}$ & $7.39 \mathrm{c}$ & $332.80 \mathrm{f}$ \\
100 & $100.00 \mathrm{a}$ & $42.51 \mathrm{k}$ & $4.13 \mathrm{~d}$ & $5.13 \mathrm{~d}$ & $185.50 \mathrm{~h}$ \\
\hline
\end{tabular}

Means within the same column having a common letter(s) do not differ significantly $(\mathrm{p}=0.05)$. .।

Plant height and stem number: At different levels of infected seed tubers, the plant height and stem number per bill ranged, respectively, 41.98-59.84 cm and 4.00-8.76 under non-spraying and 42.51-61.42 cm and 4.13-9.06 under spraying condition. Under non-spraying and spraying conditions, maximum plant height and stem number was recorded at $0 \%$ and minimum at $100 \%$ inoculum level. All 1evels caused significant reduction in both the growth parameters as compared to PLRV free seed tubers (Table 1). The reduction increased with the increased level of inoculum. The relationship of plant height and stem number was positive and linear with inoculum level (Fig. 2 and 3). 


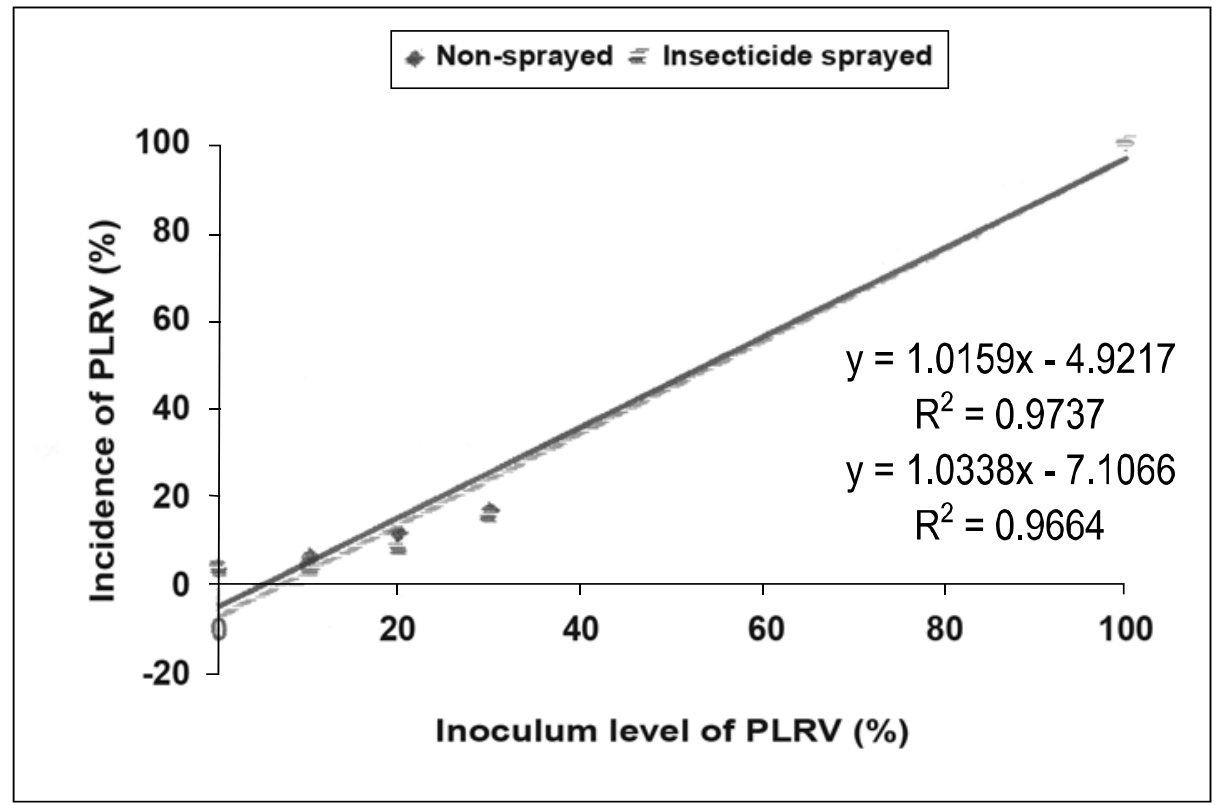

Fig. 1. Relationship between incidence of PLRV in potato field and level of infected seed tuber.

Tuber number and weight: Number of tubers per hill ranged 5.02-9.23 and 5.13-9.24 and weight of tuber ranged 175.70-448.20 and 185.50-456.70 g/hill under non-spraying and insecticide spraying conditions. Difference between tuber number per hill under non-spraying and insecticide spraying conditions was not significant at the same levels of infected seed tuber. Tuber number decreased significantly over control at $20 \%$ and higher level of infected seed. Tuber weight decreased significantly even at the lowest level of inocula as compared to control. The influence of insecticide spray on tuber weight was significant as compared to non-sprayed condition (Table 1).

Infected seed tubers at different levels caused significant reduction in number and weight of tuber. Higher reduction in number and weight of tubers per hill was corroborated with higher levels of inoculum and the relationship was positive and linear. In each case, coefficient of determination indicates that the reduction in tuber number and weight could be attributed to inoculum level of PLRV in seed tubers by more than 94\% (Fig. 4 and 5).

The results of the present investigation show that use of PLRV infected seed tubers causes reduction in yield contributing characters, such as number and weight of tubers per plant. The findings are in agreement with the findings of other investigators (Anon., 1990; Broadbent et al., 1962; de Bokx and van der Want 1987; Halim,1999; Hossain, 1999). 


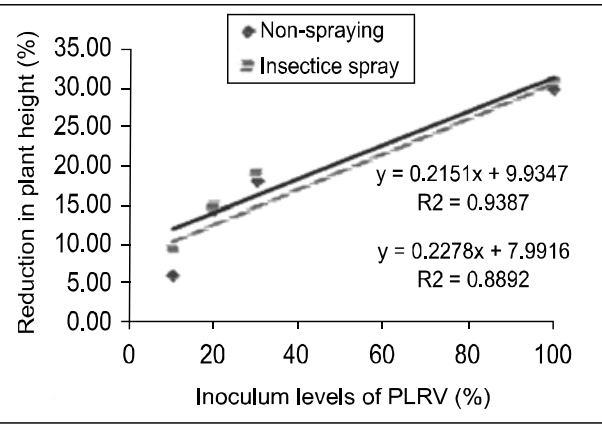

Fig. 2. Relationship between plant height of potato and level of PLRV infected seed tuber.

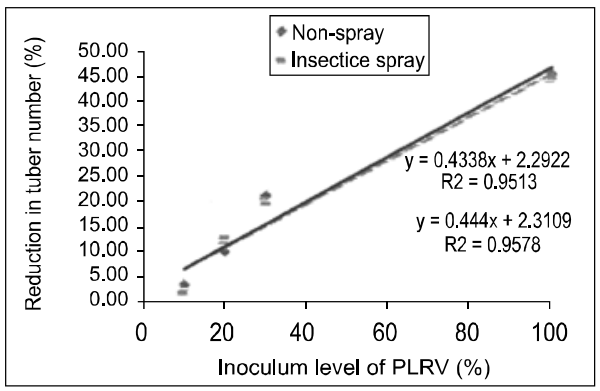

Fig. 4. Relationship between reduction in tuber number of potato and level of PLRV infected seed tuber.

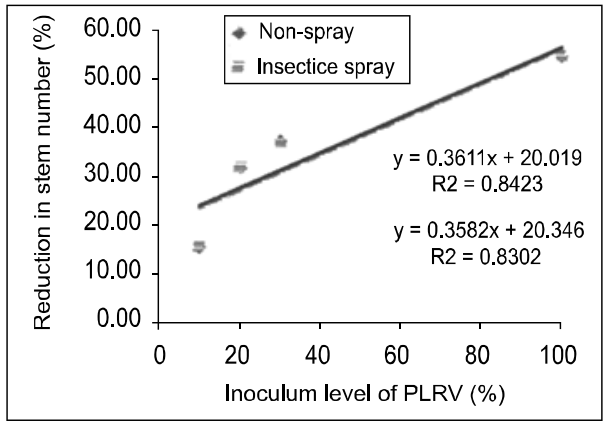

Fig. 3. Relationship between stem number of potato per hill and level of PLRV infected seed tuber.

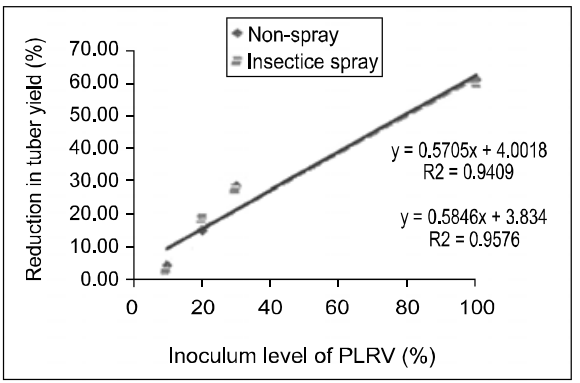

Fig. 5. Relationship between reduction in tuber yield of potato and level of PLRV infected seed tuber.

Grade of seed potato: The size of the tuber is an important factor contributing to the total yield of potato crop. The reduced yield of a diseased plant consists of tubers that are smaller than those yielded by healthy plant. It was found that the highest percentage of under sized tubers $(<28 \mathrm{~cm})$ was recorded at $100 \%$ inoculum level of PLRV. It decreased gradually with the decrease of inoculum level. This relationship was positive and linear. The influence of inoculum level this parameter could be explained by $99.96 \%$ and $99.62 \%$ when occurrence of the tuber was computed based on number and weight, respectively (Fig. 6).

Number of tubes under the grade of 28-40 mm, 41-55 mm, and $>55 \mathrm{~mm}$ was higher at $0 \%$, The tuber number under the above grades decreased with the increase of inoculum level. Their relationship with inoculum levels was negative but linear. The effect of inoculum level on these parameters could be explained by $84.22 \%, 43.81 \%$, and $65.70 \%$, for the tuber grade A. B, and over, respectively, when occurrence of the tuber was computed on the basis of number (Fig. 7).

In case of tuber grade by weight, the highest percentage of A-grade tubers (28-40 mm) was recorded when 100\% healthy tubers were planted. Their 
occurrence decreased with the increase of inoculum level. Its relationship with the inoculum level was negative and linear. The $\mathrm{R}^{2}$ value indicates that the occurrence of A-grade tuber could be attributed to inoculum level of PLRV by $37 \%$ only. Grade comprising tubers of $41-55 \mathrm{~mm}$ and $>55 \mathrm{~mm}$ were positively and negatively correlated, respectively, with different levels of PLRV infected seed tubers but the relationship was not significant (Fig. 8).

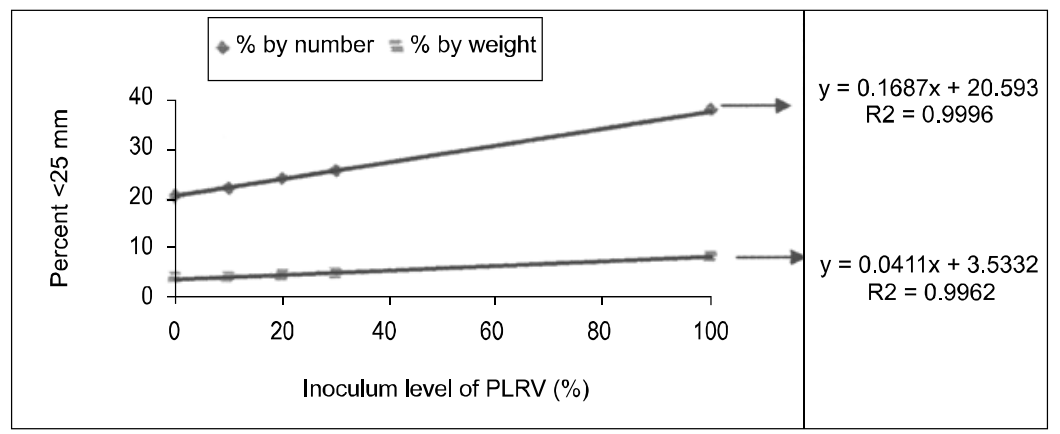

Fig. 6. Relationship of occurrence of smallest sized potato tuber (\%) with level of PLRV infected seed tuber.

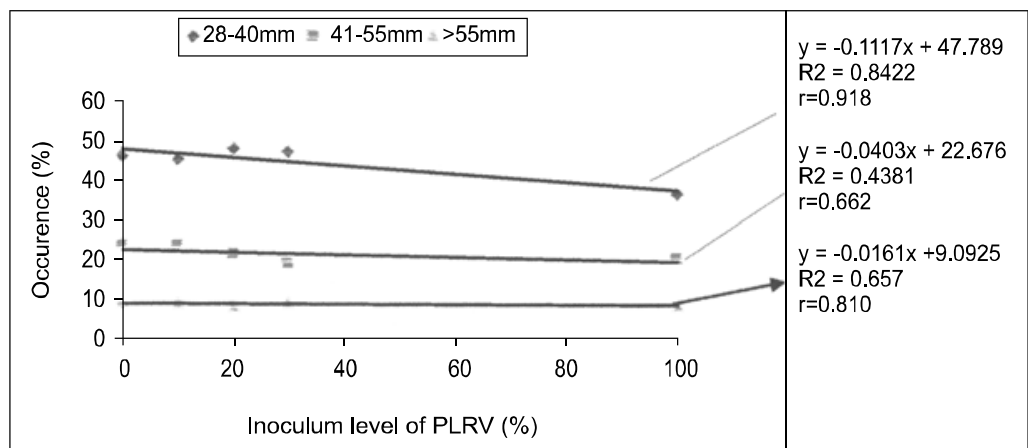

Fig. 7. Relationship of the occurrence by number (\%) $28-40 \mathrm{~mm}, 41-55 \mathrm{~mm}$, and $>55 \mathrm{~mm}$ sized potato tuber with level of PLRV infected seed tuber.

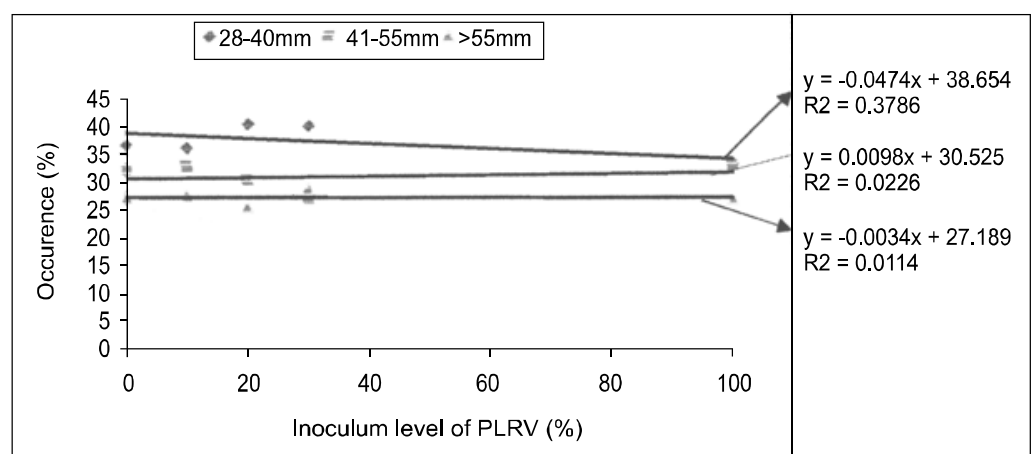

Fig. 8. Relationship of the occurrence by weight (\%) $28-40 \mathrm{~mm}$, $41-55 \mathrm{~mm}$, and $>55 \mathrm{~mm}$ sized potato tuber with level of PLRV infected seed tuber. 
The production of different sized tubers was found to be significant at different levels of infected seed tubers Similar trend was reported by de Bokx and van der Want (1987), Anon. (1993), Sanger et al. (1994), Islam (1998), Halim (1999) and Hossain (1999).

In the present investigation, it was observed that for potato production up to $10 \%$ PLRV infected plants in the field did not cause significant yield loss and spread of the disease increase with the increase in inoculum levels of PLRV. In respect of non-spraying and insecticide spraying condition, yield loss was comparatively low in the latter case. It indicates that PLRV can be controlled to some extent by spraying of insecticides as because the virus is spread in the field only by aphid vector in persistent manner (Beemstcr, 1979).

\section{References}

Akanda, A.M., K. Tsuno, and S. Wakimoto. 1991. Serological detection of tuber plant viruses in cucurbitaceous crops from Bangladesh. Ann Phytopath Soc. Japan 57: 499-505.

Anonymous. 1990 Annual Report, 1989-90. Tuber Crops Research Centre (TCRC), BARI. Joydebpur, Gazipur.

Anonymous. 1993 Annual Report 1992-93. Tuber Crops Research Sub centre, Agril. Res. StatIon. BARI. Bogra.

Anonymous. 2004. Annual Report 2003-04. Tuber Crops Research Centre (TCRC), BARI, Joydcbpur. Gazipur.

Beemster, A.B.R. 1979. Leaf Roll. Y and X viruses of potato. Proc $2^{\text {nd }}$ Workshop on Potato Research Works 103.

Broadbent L., G D Heathcote and R.C.M Wright. 1962. Home production of seed for early potatoes, 4. Loss of yield in virus infected plants. Experimental Horticulture 7: 4-6.

Clark. M.F. and A.N. Adams, 1977. Characteristics of the microplate method of enzyme linked immunosorbent assay for the detection of plant viruses. J. Gen Virol. 34: 475-483.

de Bokx, J.A. and J.P.H. van der Want. 1987. Viruses of potatoes and seed potato production. $2^{\text {nd }}$ edn. Pudoc, Wageningen. 259pp.

Halim, M.A. 1999. Serological detection of PLR V and PVY from certified potato seeds and their impact on yIeld. Thesis of MS in Plant Path, BSMRAU. 80pp.

Harper, F.R., G.A. Nelson, and U.J. Pittman, 1975. Relationship between leaf roll symptoms and yield in Netted Gem Potato. Phvtopathology 65: 1242-1244

Hossain, M., M.S. Ali, A.L.Khan and S.A. Mia. 1989. Effect of PLRV on the growth and yield of potato. Bangladesh J. Bot. 18(1): 15-21.

Hossain, M.H. 1999. Studies of different aspects of seed tuber infection by PLRV and PVY contributing degeneration of potato. Thesis of' MS in Plant Path. BSMRAU. 128pp. 
Islam, M.S. 1998. Serological detection of PLRV and PVY from foundation potato seeds and their impact on yield. Thesis of MS in Plant Path. BSMRAU. 70pp.

Khan, A.L., M.S. Ali, and M.A. Bari, 1991. A review of the viral diseases of potato in Rangladesh. Proceedings of First National Workshop on Tuber Crops, May 28-30, 1989, held at BARI, Joydebpur, Gazipur 286p.

Khurana, S.M.P and M.N. Singh. 1986. Viral and mycoplasma diseases of potato. Rev. Trop. Plain Path. 3: 123-184.

Robertson, D.G. 1978. The effect of virus diseases on the yield of potatoes. Proc. of the Second Regional Symposium on Potato Production South-East Asia and the Pacific. 5-6 Feb. held at Los Banos, Laguna,. Philippines 21p.

Sanger, R.B.S.. H.O. Agrawal and B.B. Nagaich. 1994. Studies on extent of primary infection of PVX and PVY among tubers of potatoes. Indian J. Virol. 10(1):22-

Verhocks, J .L. 1965. Photosynthesis and carbohydrate metabolism of healthy and leaf roll diseases potato plants. Thesis, Wageningen (Netherlands). Communication 43: 1-89. 